\title{
COVID-19: How do you self-isolate in a refugee camp?
}

\author{
Emmanuel Raju, ${ }^{1,2}$ (B) Sonja Ayeb-Karlsson ${ }^{3,4}$ (1)
}

Received: 8 April 2020/Revised: 8 April 2020 / Accepted: 27 April 2020/Published online: 8 May 2020

(C) Swiss School of Public Health (SSPH+) 2020

Over the last few months, we have seen how COVID-19 crossed administrative and national boundaries at the speed of fire-leaving nobody untouched. We believe that lessons learned from previous research investigating the relationships between disasters, social inequalities and how health determinants may exacerbate vulnerability will be key to overcoming the COVID-19 crisis (Quinn and Kumar 2014; Hopman and Allegranzi 2020). The reported mortality rate exceeded 200,000 this week, and the news headlines so far mainly describe 'western' endof-life-stories of elderly or people with pre-existing health conditions. However, what will happen now that the pandemic has entered ultra-vulnerable places such as refugee camps and informal settlements in the global south?

'Wash your hands, self-isolate, social distancing, please!'-but how do you self-isolate in a refugee camp?

Refugee camps and slums are socially constructed and often considered temporary 'places'. However, some of these 'temporary places' have existed for decades and have housed several generations. The COVID-19 pandemic has turned these places into ticking bombs, waiting to explode, it is just a question of time. Infectious diseases will easily wreak havoc given the social and physical conditions. Building on our research experience around climate-induced health risks and migration, as well as urban immobility, and health in informal settlements, we want to draw urgent attention to some of the current living

Emmanuel Raju

eraju@sund.ku.dk

1 Global Health Section, Department of Public Health, Copenhagen Centre for Disaster Research (COPE),

University of Copenhagen, Øster Farimagsgade, 5 Building 24, Copenhagen, Denmark

2 African Centre for Disaster Studies, North-West University, Potchefstroom, South Africa

3 University of Sussex, Brighton, UK

4 United Nations University - Institute for Environment and Human Security, Bonn, Germany conditions and scenarios that we will need to safeguard around:

\section{Refugee camps}

The first confirmed COVID-19 case in Lesbos, Greece, raised immediate concerns about the virus entering this vulnerable social setting. The Guardian describes Moria camp in Lesbos as overcrowded with 20,000 people in a space built for 3000 , while struggling to access water. ${ }^{1}$ In refugee camps, volunteers, UN agencies and NGOs generally manage the healthcare services (Carballo et al. 2017). The global COVID-19 response here is not only troubling, but unfortunately negligible with refugee populations across the world. The first case of COVID-19 has also been confirmed in Cox's Bazar, Bangladesh near the refugee camps that are already facing infectious outbreaks due its dense population, poor sanitation and lack of water, putting extreme pressure on insufficient health resources. The camps are home to the Rohingya who fled violent persecution in Myanmar. Fear among the refugees in regards to COVID-19 is currently spreading due to misinformation; or as one person stated 'If anyone gets infected, the authority has to kill her/him. Because if (s)he stays alive, the virus will transfer to another person's body.' (ACAPS 2020, p. 4). A COVID-19 outbreak would, as observed, put additional pressures on the strained healthcare services and the already-conflict traumatised population. Bangladeshi healthcare workers have expressed concerns over the lacking test kits and challenges of social (physical) distancing.

2. Informal settlements and urban slums

About a billion people around the world live in slums, including roughly $30-50 \%$ of the urban population in the Global South (Lilford et al. 2017). In Dhaka's and Mumbai's informal settlements, most cannot 'work from home'. Lacking livelihood, financial and social security, people

\footnotetext{
${ }^{1}$ For media article see, Fallon K. The Greek refugees battling to prevent Covid 19 with handmade face masks. The Guardian. 2020; published online March 18. https://www.theguardian.com/globaldevelopment/2020/mar/18/the-greek-refugees-battling-to-preventcovid-19-with-handmade-face-masks.
} 
continue with their daily lives. The environment and life in the slums generally put people at a higher risk of developing health issues (Ezeh et al. 2017; Schwerdtle et al. 2017). People live in overcrowded households and lack access to good sanitation, clean water and public health services. In our slum study sites in Dhaka and Mumbai, for example, one household (a tin shed lacking closable doors or windows) may hold up to 15 individuals. Many sleep in the same bed, and neighbours in similar conditions live wall to wall. A few public bathrooms are shared between thousands of settlers. People often settle down here after having migrated from environmental and livelihood stress elsewhere involving traumatic events. Most people work in informal sectors and are left out of the healthcare and social safeguarding systems. Further, stigma, forced evacuations and structural mistreatment cause mistrust for the government (Ayeb-Karlsson et al. 2016, 2020). In India, the media reported the first case of COVID-19 in a slum with 23,000 people in less than a square kilometre in Mumbai. The infected woman lives with six others in a 250 square feet room. Contact tracing of people sharing the public bathroom with the infected woman has become impossible. ${ }^{2}$ Imaginably, WHO's COVID-19 guidelines of two metres physical distancing and $20 \mathrm{~s}$ of hand washing with soap will not be enough (Kluge et al. 2020). The lockdown in India without any notice has left millions of daily wage labourers stranded on their way home or stuck in slums without an income while worrying about how to put food on the table. People trapped en route home are currently gathering streets and squares in large crowds awaiting government supplied meals. 'I will die of hunger long before the virus gets me' has been the standard response to any media coverage. ${ }^{3}$

Based on our experience in disaster preparedness among vulnerable populations, we suggest to:

- Upscale testing to identify, isolate and treat people early on.

- Provide financial and social support to safeguard people who cannot work from home to avoid unnecessary movements.

\footnotetext{
${ }^{2}$ For media article see, Barnagarwala T. Case in a Mumbai Slum: Officials hit tracking hurdle. Indian Express. 2020; published online March 21. https://indianexpress.com/article/india/coronavirus-casein-a-mumbai-slum-officials-hit-tracking-hurdle-6324652/.

${ }^{3}$ For more details, see Ellis-Petersen H. and Rahman SA. 'I just want to go home': the desperate millions hit by Modi's brutal lockdown. The Guardian 2020; published online April 4. https://www.theguar dian.com/world/2020/apr/04/i-just-want-to-go-home-the-desperatemillions-hit-by-modis-brutal-lockdown and, Dhillon A. Divided Delhi under lockdown: "If coronavirus doesn't kill me, hunger will." The Guardian 2020; published online March 30. https://www.the guardian.com/global-development/2020/mar/30/divided-delhi-underlockdown-if-coronavirus-doesnt-kill-me-hunger-will.
}

- Emphasise how handwashing and social (physical) distancing can save lives through social media and entrusted figures such as NGO workers and religious leaders, and set up free hand washing stations.

- Mitigate health risks before they become unmanageable. For example, set up non-traumatic temporary evacuation plans of the settlements to safe areas. This includes ensuring that people can move with their loved ones, bring valuables and safely return home after the outbreak.

- Adopt best practices from diverse case study contexts, and prepare for worst case scenarios. Preparedness plans must include increased capacity and resources of health services, global cooperation (open science, sharing testing, laboratory and medical advances) and closer collaboration between public and private healthcare sectors. Global pandemics require global solutions.

Dhaka and Mumbai are home to about 20 million people each. Clearly however, from what we have seen in Italy and China, population size does not need to imply a larger catastrophe. The COVID-19 pandemic, outlines how social inequality increases the risks for marginalised and vulnerable populations across the world. We must act nowinternational efforts must adopt a social protection strategy that saves the lives of our most fragile populations-as always it will be our most vulnerable that will suffer the most in the end!

\section{Compliance with ethical standards}

Conflict of interest The authors declare that they have no conflict of interest.

\section{References}

ACAPS (2020) COVID-19 Rohingya response. ACAPS, Geneva. Available at: https://www.acaps.org/sites/acaps/files/products/ files/20200319_acaps_covid19_risk_report_rohingya_response. pdf

Ayeb-Karlsson S, van der Geest K, Ahmed I et al (2016) A peoplecentred perspective on climate change, environmental stress, and livelihood resilience in Bangladesh. Sustain Sci 11:679-694. https://doi.org/10.1007/s11625-016-0379-z

Ayeb-Karlsson S, Kniveton D, Cannon T (2020) Trapped in the prison of the mind: notions of climate-induced (im)mobility decision-making and wellbeing from an urban informal settlement in Bangladesh. Palgrave Commun 6(62):1-15. https://doi. org/10.1057/s41599-020-0443-2

Carballo M, Hargreaves S, Gudumac I, Maclean EC (2017) Evolving migrant crisis in Europe: implications for health systems. Lancet Glob Health 5:e252-e253. https://doi.org/10.1016/S2214109X(17)30040-2

Ezeh A, Oyebode O, Satterthwaite D et al (2017) The history, geography, and sociology of slums and the health problems of 
people who live in slums. Lancet 389:547-558. https://doi.org/ 10.1016/S0140-6736(16)31650-6

Hopman J, Allegranzi B (2020) Managing COVID-19 in low- and middle-income countries. JAMA. https://doi.org/10.1001/jama. 2020.4169

Kluge HHP, Jakab Z, Bartovic J et al (2020) Comment refugee and migrant health in the COVID-19 response. Lancet 2019:2019-2020. https://doi.org/10.1016/S0140-6736(20)30791-1

Lilford RJ, Oyebode O, Satterthwaite D et al (2017) Improving the health and welfare of people who live in slums. Lancet 389:559-570. https://doi.org/10.1016/S0140-6736(16)31848-7
Quinn SC, Kumar S (2014) Health inequalities and infectious disease epidemics: a challenge for global health security. Biosecur Bioterror 12:263-273. https://doi.org/10.1089/bsp.2014.0032

Schwerdtle P, Bowen K, McMichael C (2017) The health impacts of climate-related migration. BMC Med 16:1-7. https://doi.org/10. 1186/s12916-017-0981-7

Publisher's Note Springer Nature remains neutral with regard to jurisdictional claims in published maps and institutional affiliations. 